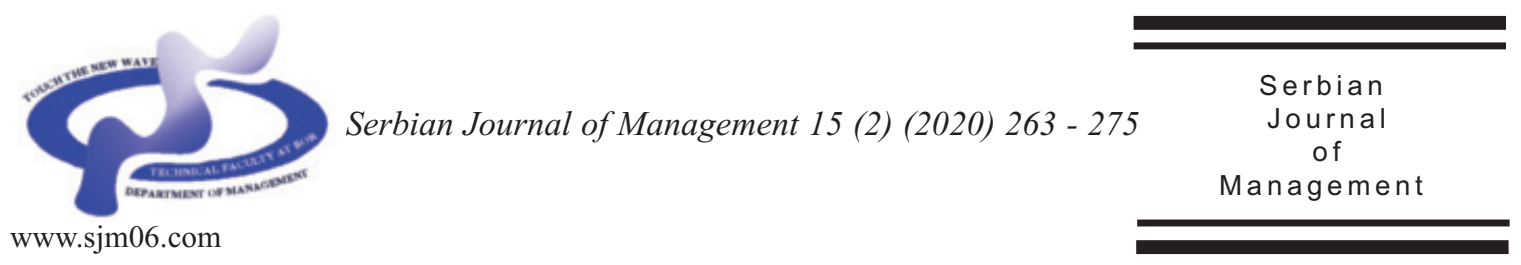

\title{
DYNAMIC ESTIMATION OF THE LOCAL BUSINESS ENVIRONMENT IN SUPPORT TO INVESTMENT DECISIONS OF THE TOP MANAGERS
}

\author{
Denitsa Petkova Zagorcheva ${ }^{a *}$ and Daniel Yordanov Pavlovb

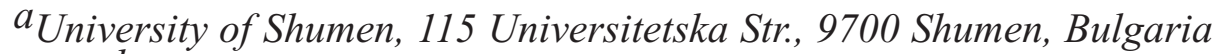 \\ ${ }^{b}$ University of Ruse, 8 Studentska Str., 7017 Ruse, Bulgaria
}

(Received 05 September 2018; accepted 01 April 2020)

\begin{abstract}
Every manager has some investment ideas for business development. Some of the investments are related to a construction of production facilities in new locations and the investors face variety of risks, which even could stop the initial development plans. Many of these risks are due to the lack of reliable data about the business environment in the new areas. Failing the preparation, they would get heavy financial losses. Here comes the science to empower them with proper economic models.

The aim of this article is to present how an economic model for estimation of the local business environment can be applied to some Bulgarian cities on the base of the municipality tax system and the local investment policy. Thus the entrepreneurs would be able to compare the business environment in different municipalities, as well as to identify possible dynamics in their trends.
\end{abstract}

Keywords: business environment, estimation, tax policy, municipality

\section{INTRODUCTION}

What are the main responsibilities of the managers? The scientists answer quite differently on this question. For example, Kunev et al. (2017), Antonova (2017), Ubreziova and Moravcikova (2017) give priority to the Corporate Social Responsibility. Dimitrova and Nikolova

*Corresponding author:danapzk@gmail.com

DOI:doi.org/10.5937/sjm15-18782
(2017) even propose new approach towards the core of the Corporate Social Responsibility. Mihajlovic et al. (2016) puts the environment awareness as a universal European value, rising the nature-protection role of the industrial firms. Pavlov et al. (2017) put reverse intergenerational family businesses as a way to keep the regional social and financial capital in the 
municipalities and to encourage the intersectoral industrial linkages. Avramova (2017) relies mostly on the public-private partnership for the improvement of the business environment. Despite of the fact that there are variety of expectations towards the managers, only in case of a financial profit their firms are eligible for a long-term existence.

On the other side, the municipalities councils and their mayors constantly search how to keep the taxpayers (firms and citizens) in their regions, as well as to attract new investors, who would improve the local socio-economic conditions. The competition among the municipalities is becoming stronger, which in return, provokes the local public administration to apply different instruments to improve the business environment. According Mingaleva et al. (2017) the networking in the cities has among the main goals also to attract financial flows (by investors or customers). But the managers need also evidence that the municipality business environment has a certain level of development.

A research work (Zagorcheva \& Pavlov, 2016) studied some of the existing well known economic models for business environment analyses and found supporting arguments towards the elaboration of a new applied scientific instrument, which to facilitate the entrepreneurs in their studies to start a new venture. This scientific work recommends the basic requirements and features of the new economic model; it should be related to: reduced subjectivism; easy access to public-accessible information; capability to show the dynamic indicators of the local business environment - especially the financial and investment policies of the municipalities; possibility to generate aggregated and comparable quantitative estimations of the business environment in the municipalities, and also, to give well informed opportunity for the industrial entrepreneurs to take reasonable investment decisions. These recommendations are in benefit to the managers; they have been applied for the development and the approbation of a new economic model for estimation of a local business environment. In the next chapters we give the general theoretical frame of this model and the basic findings from its approbation in some Bulgarian municipalities.

\section{THEORETICAL DESCRIPTION OF A NEW MODEL FOR ESTIMATION OF THE LOCAL BUSINESS ENVIRONMENT}

The local taxes have a strong influence on the local business environment. This influence could be measured by elaboration of a matrix with criteria, applicable to all Bulgarian municipalities. The methodology is based on a complex multidisciplinary approach, because of the complicated economic nature of this issue. The model's final outcome is an estimation on the base of analytical approach, structural and dynamical statistical analyses.

In accordance to the Bulgarian Public Finance Act (2016), every municipality is obliged to publish their main financial documents online, with free access from all internet users. Therefore, a strong advantage of the model is that every manager is capable to apply it independently, having this free and full access to the required financial data and tax regulations.

The here elaborated model includes some basic parameters (independent variables):

- Selected indicators about the 
municipality tax regime and municipality investment policy. The data are taken from the official documents of the municipalities, published on their official web-sites.

- Measures of each criteria - the levels are calculated on the base of minimal and maximal values of each criteria. The measures are on three levels - 0 (lowest), 1 (middle) and 2 (highest). The punctual calculation of these levels are done by Zagorcheva (2017).

- The scales, defining the significance of each criteria, are determined on the base of inquiry among 100 experts. The punctual calculation of these levels are done by Zagorcheva (2017).

\section{Dependent variables:}

- Rating marks of each criteria;

- Rating marks of the municipality tax regime and municipality investment policy;

- General rating mark as a summary of the previous two rating marks.
Table 1 describes the detailed presentations of the model (Zagorcheva, 2017). The described criteria have some basic features:

- They are applicable for all Bulgarian municipalities.

- They have a real measurement (value, presence/absence).

- They can be defined for a specific moment or a period of time.

- They are distinguishable.

- They have defined scale of significance.

The model in Table 1 has two basic parts, which combine analyses of quality and quantity criteria to estimate the level of the local business environment. Each part has $50 \%$ significance.

Part 1 of this model shows to the managers the municipality tax regime and it is composed by two groups of quality criteria - about the local legislation features and about the local administrative features. Thus the investors get an idea about their obligations to the local public administration, in case they chose that municipality for their development plans.

\section{Table 1. Elements of a model for estimation of the local business environment}

\begin{tabular}{|c|c|c|}
\hline \multicolumn{2}{|c|}{ Type of criteria } & Criteria \\
\hline $\begin{array}{c}\text { Part A: } \\
\text { Municipality tax } \\
\text { regime }\end{array}$ & $\begin{array}{l}\text { Criteria with } \\
\text { local } \\
\text { legislation } \\
\text { features }\end{array}$ & $\begin{array}{l}\text { Size of the real estate tax defined by the municipality } \\
\text { Size of the municipality tax when buying property } \\
\text { Periodic change of the municipality taxes } \\
\text { Municipality tax concessions and incentives } \\
\text { Permanency of the legal regulations of the municipality taxes for the last } 5 \text { years }\end{array}$ \\
\hline $\begin{array}{l}\text { Quality criteria } \\
\text { Total Scale }-0.5\end{array}$ & $\begin{array}{l}\text { Criteria with } \\
\text { local } \\
\text { administrativ } \\
\text { e features }\end{array}$ & $\begin{array}{l}\text { Municipality organization for collecting of local taxes } \\
\text { Municipality restrictive policies } \\
\text { Corruption at municipality level } \\
\text { Municipality monitoring system } \\
\text { Municipality controlling system }\end{array}$ \\
\hline $\begin{array}{c}\text { Part B: } \\
\text { Municipality } \\
\text { investment policy } \\
\text { Quantity criteria } \\
\text { Total scale }-0.5\end{array}$ & $\begin{array}{l}\text { Quantity } \\
\text { criteria } \\
\text { about the } \\
\text { municipality } \\
\text { investments }\end{array}$ & $\begin{array}{l}\text { Coefficient of general investment activity of the municipality } \\
\text { Coefficient of the local investment activity divided by the own-source } \\
\text { municipality revenues } \\
\text { Coefficient of the local investment activity divided by the general investment } \\
\text { activity of the municipality } \\
\text { Coefficient of investment activity of the municipality divided by the territory of } \\
\text { the municipality } \\
\text { Coefficient of investment activity of the municipality divided by the local tax } \\
\text { revenues }\end{array}$ \\
\hline
\end{tabular}


Table 2. Scales for measuring the intermediate marks and the final marks of the model

\begin{tabular}{lccc}
\hline Scales & $\begin{array}{c}\text { Intermediate mark on Part 1 } \\
\text { Municipality tax policy }\end{array}$ & $\begin{array}{c}\text { Intermediate mark on Part 2 } \\
\text { Municipality investment policy }\end{array}$ & Final mark \\
\hline Excellent & from 1.05 to 1.28 & from 0.81 to 1.00 & from 1.85 to 2.28 \\
Very good & from 0.82 to 1.04 & from 0.61 to 0.80 & from 1.42 to 1.84 \\
Good & from 0.58 to 0.81 & from 0.41 to 0.60 & from 0.98 to 1.41 \\
Unsatisfactory & from 0.35 to 0.57 & from 0.21 to 0.40 & from 0.55 to 0.97 \\
Poor & from 0.10 to 0.34 & from 0.00 to 0.20 & from 0.10 to 0.54 \\
\hline
\end{tabular}

Part 2 of this model describes the municipality investment policy. The indicators are calculated on the base of official financial reports of the local public administration. Thus the managers understand how the municipality returns the revenues from the local taxes back to the taxpayers.

The model in Table 1 is designed as an open system. The general division in the "type of criteria" is constant, while the managers may add more indicators in column "criteria" or use some of them in accordance to their specific needs.

The data in each of the two parts define an Intermediate mark. The summery of the two Intermediate marks determine the Final mark of the local business environment. Managers can rank each municipality by the intermediate marks and by the final marks, applying the scales in Table 2 .

\section{RESULTS FROM EXPERIMENTAL RESEARCH}

On 24 Aug 2018, this model has been applied to estimate the dynamics of local business environment in four Bulgarian municipalities. The following methodology has been applied:

First, to select two big municipalities:

- Their main cities to be also administrative centers.
- Each of them to have a local industrial park as a proof that the local municipality administrations have serious intentions to attract investors.

- All their data for the period of 2012 2016, necessary for the calculation of the intermediate and final marks of their local business environment, to be available in internet with a free access.

- To be situated in the North-East Bulgaria.

- To have population of $100000-200$ 000 .

- To have a high educational institution.

On the base of these criteria the selected big municipalities are Shumen and Ruse.

Second, to select small municipalities:

- To be within $50 \mathrm{~km}$ from the selected big municipalities.

- To have some industrial firms from different sectors.

- All their data for the period of 2012 2016, necessary for the calculation of the intermediate and final marks of their local business environment, to be available in internet with a free access.

On the base of these criteria the selected small municipalities are Kaspichan and Dve Mogili.

Third, searching for the related municipality data covering the period of 
2012 - 2016, necessary for the calculation of the intermediate and final marks of their local business environments. The internet search has been done on 24 Aug 2018, using two main sources of information:

1. The official documents of the four municipalities, published for free on their official web-sites:

A. Data at the official web-site of the municipality of Shumen:

- Shumen Municipality Council. Financial reports of the Shumen municipality budget, extra budget accounts and funds for 2012, 2013, 2014, 2015 and 2016.

- Shumen Municipality Council. Decree for defining the values of the local taxes for the territory of the Shumen municipality. Approved with Decision №31 from 12 Feb 2008, last changed by Decision №263 from 29 Sep 2016.

B. Data at the official web-site of the municipality of Ruse:

- Ruse Municipality Council. Financial reports of the Ruse municipality budget, extra budget accounts and funds for 2012, 2013, 2014, 2015 and 2016.

- Ruse Municipality Council. Decree №20 for defining the values of the local taxes for the territory of the Ruse municipality. Approved with Decision №79 from 28 Feb 2008, last changed by Decision №401 from 15 Dec 2016.

C. Data at the official web-site of the municipality of Kaspichan:

- Kaspichan Municipality Council. Financial reports of the Kaspichan municipality budget, extra budget accounts and funds for 2012, 2013, 2014, 2015 and 2016.
- Kaspichan Municipality Council. Decree for defining the values of the local taxes for the territory of the Kaspichan municipality. Approved with Decision №50 from 25 Jan 2008, last changed by Decision №307 from 24 Nov 2016.

D. Data at the official web-site of the municipality of Dve Mogili:

- Dve Mogili Municipality Council. Financial reports of the Dve Mogili municipality budget, extra budget accounts and funds for 2012, 2013, 2014, 2015 and 2016.

- Dve Mogili Municipality Council. Decree №1 for defining the values of the local taxes for the territory of the Dve Mogili municipality. Approved with Decision №74 from 01 Feb 2008, last changed by Decision №366 from 29 Oct 2016.

2. The Internet based platform for training the local authorities, supported and maintained by the National Association of Municipalities in the Republic of Bulgaria:

- Inquiry about the municipality revenues.

- Inquiry about the municipality expenditures.

- Inquiry about the municipality territories.

Fourth, to calculate the criteria for each municipality.

Fifth, to give a good visualization of the results by tables and figures.

The findings per municipality are given in the Table 3-6. Then in Table 7-9 and Figures 1-3 we compare the municipalities. The comments of the results are in the next chapter "Discussion". 
Table 3. Estimation of the local business environment of Shumen municipality

\begin{tabular}{cccccc}
\hline $\begin{array}{c}\text { Shumen } \\
\text { municipality }\end{array}$ & \multicolumn{2}{c}{$\begin{array}{c}\text { Intermediate mark on Part 1 } \\
\text { Municipality tax policy }\end{array}$} & \multicolumn{2}{c}{$\begin{array}{c}\text { Intermediate mark on Part 2 } \\
\text { Municipality }\end{array}$} & Finvestment policy \\
\cline { 2 - 5 } Year & scale & Mark & scale & mark & scale \\
$\mathbf{2 0 1 2}$ & 0.77 & Good & 0.50 & Good & 1.27 \\
$\mathbf{2 0 1 3}$ & 0.80 & Good & 0.50 & Good & 1.30 \\
$\mathbf{2 0 1 4}$ & 0.80 & Good & 0.40 & Unsatisfactory & 1.20 \\
$\mathbf{2 0 1 5}$ & 0.80 & Good & 0.30 & Unsatisfactory & 1.10 \\
$\mathbf{2 0 1 6}$ & 0.84 & Very good & 0.30 & Unsatisfactory & 1.14 \\
\hline
\end{tabular}

Table 4. Estimation of the local business environment of Ruse municipality

\begin{tabular}{cccccc}
\hline $\begin{array}{c}\text { Ruse } \\
\text { municipality } \\
\text { Year }\end{array}$ & \multicolumn{2}{c}{$\begin{array}{c}\text { Intermediate mark on Part 1 } \\
\text { Municipality tax policy }\end{array}$} & \multicolumn{2}{c}{$\begin{array}{c}\text { Intermediate mark on Part 2 } \\
\text { Municipality investment policy }\end{array}$} & Final mark \\
\cline { 2 - 6 } $\mathbf{2 0 1 2}$ & scale & Mark & scale & Mark & scale \\
$\mathbf{2 0 1 3}$ & 0.84 & Very good & 0.30 & Unsatisfactory & 1.14 \\
$\mathbf{2 0 1 4}$ & 0.84 & Very good & 0.30 & Unsatisfactory & 1.14 \\
$\mathbf{2 0 1 5}$ & 0.84 & Very good & 0.80 & Very good & 1.64 \\
$\mathbf{2 0 1 6}$ & 0.84 & Very good & 0.30 & Unsatisfactory & 1.14 \\
\hline
\end{tabular}

Table 5. Estimation of the local business environment of Kaspichan municipality

\begin{tabular}{cccccc}
\hline $\begin{array}{c}\text { Kaspichan } \\
\text { municipality } \\
\text { Year }\end{array}$ & \multicolumn{2}{c}{$\begin{array}{c}\text { Intermediate mark on Part 1 } \\
\text { Municipality tax policy }\end{array}$} & \multicolumn{2}{c}{$\begin{array}{c}\text { Intermediate mark on Part 2 } \\
\text { Municipality investment policy }\end{array}$} & Final mark \\
\cline { 2 - 5 } 2012 & scale & Mark & scale & mark & scale \\
2013 & 0.73 & Good & 0.13 & Poor & 0.86 \\
2014 & 0.88 & Very good & 0.10 & Poor & 1.01 \\
2015 & 0.88 & Very good & 0.13 & Poor & 1.05 \\
2016 & 0.92 & Very good & 0.13 & Poor & 1.05 \\
\hline
\end{tabular}

The marks in Table 3 estimate the local business environment in Shumen municipality as "Good". Despite of the small changes during the years, the trend remains constant.

The marks in Table 4 estimate the local business environment in Ruse municipality. The fluctuations in the final marks "Good" and "Very good" are mainly due to the big dynamic in the municipality investment policy.

The marks in Table 5 estimate the local business environment in Kaspichan municipality. Although the municipality tax policy is constantly improving, keeping high score, the municipality investment policy remains poor.
The marks in Table 6 estimate the local business environment in Dve Mogili municipality. Although the municipality tax policy is constantly improving, keeping high score, the municipality investment policy remains poor.

Table 7 and Figure 1 describe the dynamics in the intermediate marks of the municipality tax policies.

Table 8 and Figure 2 describe the dynamics in the intermediate marks of the municipality investment policies.

The next Table 9 and Figure 3 help the managers to compare the final marks of the local business environments per years of the four municipalities. 
Table 6. Estimation of the local business environment of Dve Mogili municipality

\begin{tabular}{cccccc}
\hline $\begin{array}{c}\text { Dve Mogili } \\
\text { municipality }\end{array}$ & \multicolumn{2}{c}{$\begin{array}{c}\text { Intermediate mark on Part 1 } \\
\text { Municipality tax policy }\end{array}$} & \multicolumn{2}{c}{$\begin{array}{c}\text { Intermediate mark on Part 2 } \\
\text { Municipality investment policy }\end{array}$} & Final mark \\
\cline { 2 - 5 } Year & scale & Mark & scale & mark & scale \\
2012 & 0.97 & Very good & 0.10 & Poor & 1.07 \\
2013 & 0.93 & Very good & 0.10 & Poor & 1.03 \\
2014 & 0.97 & Very good & 0.33 & Unsatisfactory & 1.30 \\
2015 & 0.97 & Very good & 0.33 & Unsatisfactory & 1.30 \\
2016 & 0.97 & Very good & 0.10 & Poor & 1.07 \\
\hline
\end{tabular}

Table 7. Intermediate marks of the Municipality tax policy

\begin{tabular}{ccccc}
\hline Years & Shumen & Ruse & Kaspichan & Dve Mogili \\
\hline 2012 & 0.77 (Good) & 0.84 (Very good) & 0.73 (Good) & 0.97 (Very good) \\
2013 & $0.80($ Good) & 0.84 (Very good) & 0.88 (Very good) & 0.93 (Very good) \\
2014 & $0.80($ Good) & 0.84 (Very good) & 0.88 (Very good) & 0.97 (Very good) \\
2015 & $0.80($ Good) & 0.84 (Very good) & 0.92 (Very good) & 0.97 (Very good) \\
2016 & 0.84 (Very good) & 0.78 (Very good) & 0.92 (Very good) & 0.97 (Very good) \\
\hline
\end{tabular}

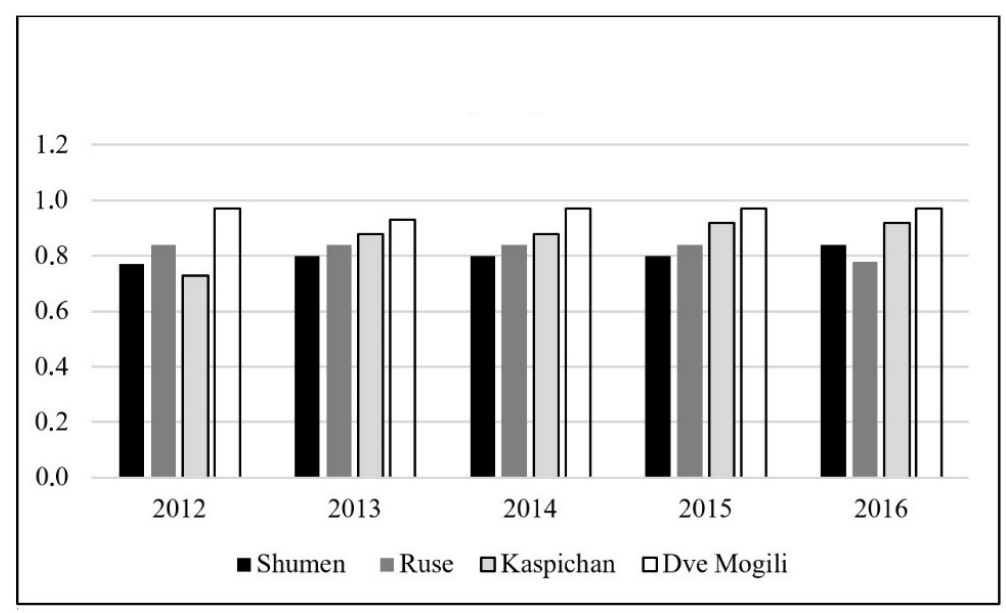

Figure 1. Intermediate marks of the municipality tax policy

Table 8. Intermediate marks of the Municipality investment policy

\begin{tabular}{ccccc}
\hline Years & Shumen & Ruse & Kaspichan & Dve Mogili \\
\hline 2012 & 0.50 (Good) & 0.30 (Unsatisfactory) & 0.13 (Poor) & 0.10 (Poor) \\
2013 & 0.50 (Good) & 0.30 (Unsatisfactory) & 0.10 (Poor) & 0.10 (Poor) \\
2014 & 0.40 (Unsatisfactory) & 0.80 (Very good) & 0.13 (Poor) & 0.33 (Unsatisfactory) \\
2015 & 0.30 (Unsatisfactory) & 0.30 (Unsatisfactory) & 0.13 (Poor) & 0.33 (Unsatisfactory) \\
2016 & 0.30 (Unsatisfactory) & 0.80 (Very good) & 0.13 (Poor) & 0.10 (Poor) \\
\hline
\end{tabular}




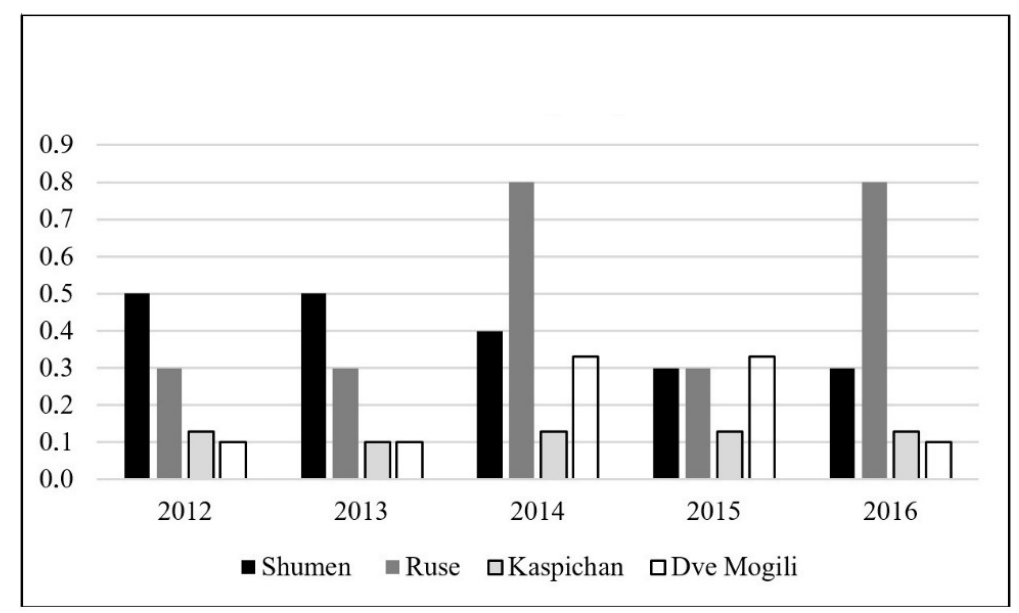

Figure 2. Intermediate marks of the local municipality investment policy

Table 9. Final marks of the local business environments

\begin{tabular}{|c|c|c|c|c|}
\hline Years & Shumen & Ruse & Kaspichan & Dve Mogili \\
\hline 2012 & 1.27 (Good) & 1.14 (Good) & 0.86 (Good) & 1.07 (Good) \\
\hline 2013 & 1.30 (Good) & 1.14 (Good) & 1.01 (Good) & 1.03 (Good) \\
\hline 2014 & $1.20($ Good $)$ & 1.64 (Very good) & 1.05 (Good) & 1.30 (Good) \\
\hline 2015 & $1.10(\mathrm{Good})$ & 1.14 (Good) & 1.05 (Good) & 1.30 (Good) \\
\hline 2016 & 1.14 (Good) & 1.58 (Very good) & 1.05 (Good) & 1.07 (Good) \\
\hline
\end{tabular}

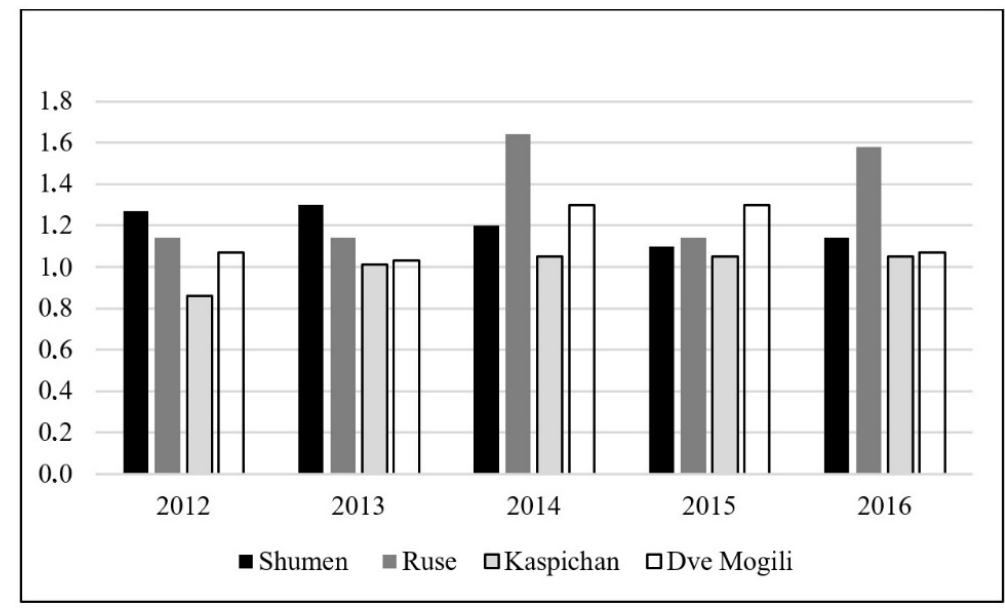

Figure 3. Final marks of the local business environments

Comparing the results in the three figures it is possible to show that the big municipalities have better opportunities for local investment policy, while the small municipalities have to rely mostly on the improved tax policy towards the investors. 


\section{DISCUSSION}

\subsection{Business environment of Shumen municipality for the period 2012 - 2016}

The intermediate marks of the Shumen municipality tax policy present slow dynamics in the years (Table 3). The improvement of the local business environment is slow despite of the higher marks in the last year of the period.

From one side the local public administration introduces restrictive policies, concerned to the regulations of the regime of the local taxes affecting the firms and the citizens. As a consequence of this change there is a negative effect on the value of this intermediate mark.

On the other side, there are big improvements of the municipality controlling system. Before 2013, the local public administration applies only those controlling regimes, which are obliged by the legislation. Since 2013, the local public administration has initiated additional controlling regulations to release the process of the tax administrative procedures. The improvements contribute for the bigger increase of the values of the first intermediate mark, compensating the above described restrictions.

In 2016, there is another positive result of the local public administration activity there is a permanency of the local legal regulations, which facilitates the business activity of the managers.

On the base of these changes, the model estimates that the first intermediate mark for 2016 is higher, compared to the previous years - from "Good" to "Very good".

The second intermediate mark Municipality investment policy has a negative trend through the years. During the analysed period the values of this mark declines from "Good" to "Unsatisfactory" (from 0.5 to 0.3 ). There are several reasons: from one hand, during the years, the size of the municipality investments decreases. On the other hand, the municipality revenues and municipality expenses increase. Thus, in the mathematical calculations of this coefficient, the values of this coefficient decrease in the years.

The final mark of the local business environment remains "Good", although its values decrease in the years from 1.27 to 1.14. The two intermediate marks have opposite trends and thus they compensate the changes, keeping the final mark comparatively the same.

These analyses should direct the managers to look at the final mark, but also to take into serious consideration the intermediate marks, too. Thus the investors may analyse the risks in the Municipality tax policy and the risks in the Municipality investment policy. The fact that the final mark of the business environment has small changes in the years, could mislead the managers that the municipality has a sustainable policy. The two intermediate marks clearly describe the municipality advantages and disadvantages and facilitate the managers in their decisions if to allocate in this municipality the construction of new industrial premises.

\subsection{Business environment of Ruse municipality for the period $2012-2016$}

The first intermediate mark, related to the local municipality tax policy is permanently calculated as "Very good" (Table 4) for all five years. Only in the last year the value is reduced (from 0.84 to 0.78 ), because of two opposite changes: From one side, there is a 
permanency of the local legal regulations, but on the other hand, there is a drastic increase of the rates of the real estate tax. Thus, in general the intermediate mark remains "Very good", with a slight decrease in the coefficient.

The changes in the second intermediate mark, concerning the municipality investment policy, are quite dramatic. During two of the years $\left(2014^{\text {th }}\right.$ and $\left.2016^{\text {th }}\right)$ there is a tremendous change in the estimation from "Unsatisfactory" to "Very good". It is a result of a positive change in all five coefficients of the Part 2. It is a strong indicator for the managers that the municipality has a high investment capacity.

The final mark of the local business environment of Ruse municipality is a good indicator for the investors. In general, the values of this mark increase from "Good" to "Very good". The higher values of the final mark for $2014^{\text {th }}$ and $2016^{\text {th }}$ show a trend of better investment activity.

\subsection{Business environment of} Kaspichan municipality for the period 2012 - 2016

The first intermediate mark, related to the municipality tax policy is permanently calculated as "Very good" (Table 5) for most of the years. It is an indicator for the investors that the local public administration is capable not only to develop very good municipality tax policy, but also to keep it during the years.

In contrast, the second intermediate mark on the municipality investment policy is low. During the entire period the mark is "Poor". It is indicator for the investors that the municipality doesn't have investment capacity to improve the local business environment. It could lead to emigration of people, poor infrastructure and many other negatives.

The final mark on the local business environment remains the same in the years "Good". The values slightly increase, because of the very good municipality tax policy. The investors should develop very good collaboration with the local authorities before investing in that region.

\subsection{Business environment of Dve Mogili municipality for the period 2012 -} 2016

The first intermediate mark, related to the municipality tax policy is permanently calculated as "Very good" (Table 6) for all the years. The values of the coefficient remain stable in the time. It is an indicator for the investors that the local public administration is capable to keep very good municipality tax policy during the years. The managers should seriously to develop new industrial facilities in this region.

The second intermediate mark on the municipality investment policy remains low during the years, estimated as "Poor" and "Unsatisfactory". As a small municipality, it has limited capacity for investment policy for improvement of the local business environment. It could lead to emigration of people, poor infrastructure and many other negatives.

The final mark on the local business environment remains the same in the years "Good". The high levels of the municipality tax policy in the years keep this final mark, but the managers should develop very good collaboration with the local authorities before investing in that region in order to compensate the low level of municipality investment in the local business environment. 


\section{CONCLUSIONS}

The model could be used by the managers in two main directions: to compare the business environment of different municipalities; to identify specific dynamics of the business environment in one municipality by years. On the base of the outcomes, the investor could identify the municipality with better business environment for their development plans.

This model could give significant support to variety of stakeholders, who need to estimate the role of the local taxes and local investment policy in configuration of the local business environment. The here presented analyses could be used by variety of interested parties, mainly:

- Managers - in their investment efforts to find new areas (municipalities) where to construct new production facilities OR to decide if to remain their activity in the already occupied municipality.

- Municipality public administration they may use this model for assessment of their local business environment and identify the directions for its improvement.

The here described examples of estimation of the business environment of the four municipalities show how the managers could additionally reduce the risks in their investment plans for business development - by taking into consideration the advantages and disadvantages of the business environment of a specific municipality.

The managers, who operate their firms in areas with low levels of municipality investment policy, could also study the opportunities to develop some forms of the public-private partnerships having in mind the high levels of the municipality tax policy.
The coefficients in the model could give to the local public administration some directions for initiatives which to improve the business environment and make the regions more attractive for investors and other tax-payers.

The here presented new model for estimation of the local business environment could be applied for any municipality, regardless of any limits, such as demographic, economic, natural, etc. It could be adapted to other countries, too, keeping all types of the criteria and recalculating the scales for marks - from "Poor" to "Excellent". The only precondition is to have access to the here described official documents of the municipality administration.

\section{References}

Antonova, D. (2017). Common understanding of corporate social responsibility in Bulgaria, Analele Universității "Eftimie Murgu" Reșița, Fascicola II, Studii Economice, XXIV, 7-23.

Avramova, D. (2017). Public-Private Partnership in the Example of Titan Ltd., Journal of Entrepreneurship \& Innovation, 9, 134-141.

Dimitrova, T., Nikolova, D. (2017). Integral estimation of the corporate social responsibility, Economic Thought Journal at Bulgarian Academy of Science, 4, 67-89.

Kunev, Sv., I. Kostadinova, B. Stoycheva. (2017). Business Governance and Corporate Social Responsibility in Bulgaria, Analele Universității "Eftimie Murgu" Reșița, Fascicola II, Studii Economice, XXIV, 99115.

Mihajlovic, I., Voza, D., Miloševic, I., Durkalic, D. (2016). Environmental 


\section{ДИНАМИЧКА ПРОЦЕНА ЛОКАЛНОГ ПОСЛОВНОГ ОКРУЖЕЊА КАО ПОДРШКА ИНВЕСТИЦИОНИМ ОДЛУКАМА ВРХОВНИХ МЕНАЏЕРА}

\section{Denitsa Petkova Zagorcheva, Daniel Yordanov Pavlov}

\section{Извод}

Сваки менаџер има одређене инвестиционе идеје за развој пословања. Неке од инвестиција односе се на изградњу производних погона на новим локацијама, а инвеститори се суочавају са разним ризицима, који би чак могли зауставити почетне развојне планове. Многи од ових ризика настају услед недостатка поузданих података о пословном окружењу у новим областима. Неуспех у припреми донео би велике финансијске губитке. Овде долази наука која ће их оснажити одговарајућим економским моделима.

Циљ овог чланка је да представи како се економски модел за процену локалног пословног окружења може применити на неке бугарске градове на основу општинског пореског система и локалне инвестиционе политике. Тако би предузетници могли да упореде пословно окружење у различитим општинама, као и да идентификују могућу динамику њихових трендова.

Кључне речи: пословно окружење, процена, пореска политика, општина

Awareness as a Universal European Value, Serbian Journal of Management, 11(2), 149153.

Mingaleva, Z., Sheresheva, M., Oborin, M., Gvarliani, T. (2017). Networking of small cities to gain sustainability, Entrepreneurship and Sustainability Issues, 5(1), 140-156.

Pavlov, D., Sheresheva, M., Perello, M. (2017). The Intergenerational Small Family Enterprises as Strategic Entities for the Future of the European Civilization - A Point of View, Journal of Entrepreneurship \& Innovation, 9, 26-38.

Public Finance Act. (2013). Bulgarian State Gazette, 15.

Ubreziova, I., Moravcikova, K. (2017). How to Perceive The Corporate Social Responsibility in The Agro-food Companies, Serbian Journal of Management 12 (2), 201215.
Zagorcheva, D. (2017). Research and Estimation of the Tax Policy and Investment Policy in the Municipalities as a Managed Factor of the Business Environment in Benefit to The Industrial Firms, $\mathrm{PhD}$ dissertation at the University of Ruse "Angel Kanchev", Bulgaria.

Zagorcheva, D., Pavlov, D. (2016). The Need for Elaboration of a New Economic Model for Business Environment Analysis, Journal of Entrepreneurship \& Innovation, 8, 19-27.

\section{Web references}

Dve Mogili Municipality Council. Decree №1 for defining the values of the local taxes for the territory of the Dve Mogili municipality. Approved with Decision №74 from 01 Feb 2008, last changed by Decision №366 from 29 Oct 2016. 
http://www.dvemogili.bg/pdf/aktove/naredbi /Napedba1-2016-10-28.pdf 24 Aug 2018.

Dve Mogili Municipality Council. Reports for cash execution of the Dve Mogili municipality budget, extra budget accounts and funds for 2012, 2013, 2014, 2015 and 2016. http://www.dvemogili.bg 24 Aug 2018.

Kaspichan Municipality Council. Decree for defining the values of the local taxes for the territory of the Kaspichan municipality. Approved with Decision №50 from 25 Jan 2008, last changed by Decision №307 from 24 Nov 2016. http://www.kaspichan.org/uploadfiles/obshtinski_savet/materiali/2015_2019/ 12/ndredba_danaci.pdf 24 Aug 2018.

Kaspichan Municipality Council. Reports for cash execution of the Kaspichan municipality budget, extra budget accounts and funds for 2012, 2013, 2014, 2015 and 2016. http://www.kaspichan.org 24 Aug 2018.

National Association of Municipalities in the Republic of Bulgaria, Inquiries about the municipality revenues, expenditures and territories. http://www.namrb.obuchi-se.org 24 Aug 2018.

Ruse Municipality Council. Decree №20 for defining the values of the local taxes for the territory of the Ruse municipality. Approved with Decision №79 from 28 Feb 2008, last changed by Decision №401 from 15 Dec 2016. http://obs.rusebg.eu/naredbi/26 24 Aug 2018.

Ruse Municipality Council. Reports for cash execution of the Ruse municipality budget, extra budget accounts and funds for 2012, 2013, 2014, 2015 and 2016. http://ruse-bg.eu/bg/pages/490/index.html 24 Aug 2018.

Shumen Municipality Council. Decree for defining the values of the local taxes for the territory of the Shumen municipality. Approved with Decision №31 from 12 Feb 2008, last changed by Decision №263 from 29 Sep 2016. http://www.shumen.bg 24 Aug 2018.

Shumen Municipality Council. Reports for cash execution of the Shumen municipality budget, extra budget accounts and funds for 2012, 2013, 2014, 2015 and 2016 http://www.shumen.bg 24 Aug 2018. 